\title{
The impact of exports on growth in Chile
}

\section{Ricardo Ffrench-Davis}

Principal Regional Adviser ECLAC

Professor of Economics

University of Chile

rffrenchdavis@eclac.cl
Dynamic export growth has been a distinctive feature of the Chilean economy over the last quarter of a century. This strong performance, however, has been accompanied by only modest average growth in GDP. Whilst export volumes rose by $10 \%$ a year between 1974 and 2001, GDP growth was only $4.3 \%$. Furthermore, whereas export growth was steady, GDP fluctuated greatly, with several episodes of $8 \%$ to $10 \%$ growth but also deep recessions of $14 \%$ or $15 \%$. Here we shall look at the similarities and differences among three episodes (1973-1982, 1983-1989 and 1990-1999), analyse the interrelationship among export quality, the macroeconomic environment and overall growth in Chile, and touch on some challenges for the future. 


\section{Introduction}

Dynamic export growth has been a distinctive feature of the Chilean economy over the last quarter of a century. With only the occasional reverse (the main one being in the early 1980s), goods and services exports have led economic growth and tended to rise as a proportion of national output, increasing from $15 \%$ of GDP in the 1970 s to some $30 \%$ by the beginning of this decade.

Dynamic exports, however, have been accompanied by modest average GDP growth. Whilst export volumes rose by $10 \%$ a year between 1974 and 2001, GDP growth averaged only $4.3 \%$. Whereas export growth has been quite steady, GDP has fluctuated sharply, with episodes of $8 \%$ to $10 \%$ growth but also deep recessions of $14 \%$ and $15 \%$. These fluctuations have had a significant effect on average economic growth.

The pioneering trade liberalization carried out in the 1970s, rapid export growth and the recovery in GDP observed in the Chilean economy after the 1975 crisis would seem to indicate that trade reform was a success. The outcome is not so clear-cut, however. The proimport bias of the first trade reform brought in during the 1970s, the currency appreciation that took place in the second half of the decade and mistakes with the sequencing and speed of the changes had led by the early 1980 s to a huge external deficit and to a situation that was discouraging to exporters. Although the effects were positive in the early years (Ffrench-Davis, 2002, chapter III), by 1981 most exports were losing ground in volume and value terms.

Following recovery from the 1982 debt crisis, a changed framework led to a second surge in exports. This context included a real exchange rate that depreciated sharply during the 1980 s, and proactive public policies, including a new and more pragmatic trade reform that reintroduced a degree of protection for importables and incentives for non-traditional exports. Then, in the 1990s, a third episode of export dynamism was stimulated by a more comprehensive policy that sought to combine the principles of an open economy and selective integration with certain strategic trading partners, particularly in Latin America, all this taking place in a new environment characterized by high levels of domestic investment and rising productivity across the economy until 1998. In more recent years (1999-2001) this tendency has been reversed to some degree.

Several interesting studies of Chilean export performance have come out recently. ${ }^{1}$ Here we shall concentrate on the differences among the three episodes (especially the second and third), the interrelationship between that performance and overall growth in the Chilean economy, and challenges for the future.

\section{II}

\section{Trade policy in the 1980s: a departure from neoliberal orthodoxy}

In response to the deep recession of 1982, Chile was obliged to adjust its policies to cope with severe external constraints and stimulate domestic recovery. Thus, there was a shift from a highly orthodox or neoliberal model,

$\square$ An abridged version of this article also appears in Ffrench-Davis (2002). The author is grateful for the valuable research work done by Heriberto Tapia and for the comments of Carla Macario. implemented mainly in the 1970 s and early 1980 s, to a more pragmatic approach, which included partial reversal of some of the original reforms (Ffrench-Davis, 2002, chapter VI, and Moguillansky, 1999). In this new context, the priority was to generate a trade surplus to

${ }^{1}$ See, for example, Agosin (2001); Meller and Sáez (1995); Meller (1996) and Sachs, Larraín and Warner (1999). 
service the large external debt built up between 1977 and 1982. The strategy followed involved both reducing imports and promoting exports, in three ways: an increase in the uniform tariff from $10 \%$ to $35 \%$, the use of a battery of export promotion instruments -notably a novel system of simplified drawback for non-traditional exports, or subsidy of $10 \%-$ and an active exchange-rate policy that sought to enhance the external competitiveness of the Chilean economy and its ability to generate foreign currency.

\section{Export promotion and the second trade reform}

Chile was the first Latin American country to carry out across-the-board trade liberalization, and has been the most consistent in applying it. In 1973, before the reforms began, Chile's external trade was subject to heavy State intervention. ${ }^{2}$ In late 1973 a deep trade reform was initiated. This included the abolition of all non-tariff restrictions, rapid tariff reductions and unification of the multiple exchange rates into a single rate. Although it was not one of the programme's original goals, by June 1979 a low, uniform tariff of $10 \%$ had been established (Ffrench-Davis, 2002, chapter III).

Table 1 shows how the average import tariff and real exchange rate have moved over time.

In the first trade liberalization, large tariff cuts and the dismantling of quantitative controls seem to have had a powerful impact on export dynamism, by reducing the cost of imported inputs (Agosin, 2001). The starting point was a situation in which the great majority of domestic prices for standard importables (consumer and intermediate goods) were not tied to international prices; as a result, the scope for reducing costs by replacing domestic inputs with imports and raising productivity was immense. By late 1973, furthermore, there was significant underutilization of installed capacity in the export sector, owing to the marked distortions that then prevailed in the Chilean economy. This was the main reason for the spectacular growth of exports in 1974, which began sharply a few months after the 1973 coup, along with very marked

\footnotetext{
${ }^{2}$ This was the situation in 1973. A reform programme carried out in the second half of the 1960s, however, included gradual rationalization of the import regime, improvements to export promotion mechanisms and systematic implementation of a policy of mini-adjustments to the exchange rate (Ffrench-Davis, 1973). This was the experiment that pioneered what John Williamson would later dub the "crawling peg" system, later to evolve into the system of "crawling bands".
}

TABLE 1

Chile: Average tariff and real exchange rate, 1973-2001

\begin{tabular}{lcc}
\hline Year & $\begin{array}{c}\text { Average tariff } \\
(\%)\end{array}$ & $\begin{array}{c}\text { Real exchange rate } \\
(1986=100)\end{array}$ \\
\hline 1973 & $94.0^{\mathrm{c}}$ & $65.1^{\mathrm{c}}$ \\
$1974-79$ & 35.3 & 73.2 \\
$1980-82$ & 10.1 & 57.6 \\
$1983-85$ & 22.7 & 79.1 \\
$1986-89$ & 17.6 & 106.6 \\
$1990-95$ & 12.0 & 99.5 \\
$1996-98$ & 11.0 & 80.3 \\
$1999-2001^{\mathrm{d}}$ & 9.0 & 88.4 \\
\hline
\end{tabular}

Source: Central Bank of Chile and Ffrench-Davis (2001).

a Simple average, excluding exemptions and preferential
arrangements negotiated with Latin American countries and
Canada.
b Simple average. The nominal exchange rate was deflated by the
Chilean consumer price index (duly adjusted in 1973-1978) and
inflated by an external price index. This index was constructed
on the basis of the wholesale price index, weighted for the shares
in Chilean trade of Argentina, Brazil, Canada, France, Germany,
Italy, Japan, Peru, the Republic of Korea, Spain, the United
Kingdom and the United States from 1986 onward; it was obtained
from the Central Bank of Chile. For years up to 1985, the
information is taken from Ffrench-Davis, Leiva and Madrid
(1991), and includes France, Germany, Japan, the United
Kingdom and the United States.
c December 1973 .
d Provisional figures for 2001 .

diversification. However, because of the recessionary environment in which the reform was carried out, its abruptness, the behaviour of the exchange rate (which appreciated sharply after 1975) and excessively high interest rates (an average of $38 \%$ in real terms between 1975 and 1982), the dynamism of the export sector was transmitted only very weakly to the rest of the economy. Fixed productive investment was well below historical norms, and the economy underwent a sharp deindustrialization. Lastly, banks (and thus their lending) suffered a spectacular crisis (Ffrench-Davis, 2002, chapter II).

Abrupt trade liberalization, accompanied by significant currency appreciation between the mid1970 s and the early 1980s, resulted in a major external imbalance that multiplied the effects of the highly adverse external shocks associated with the Latin American debt crisis. To cope with the domestic and balance-of-payments crisis that struck Chile in 1982 (owing to a combination of economic policy errors and 
a threefold external shock ${ }^{3}$ that reduced aggregate demand by $30 \%$ and GDP by $17 \%$ between 1981 and 1983), the currency was devalued on a number of occasions from mid-1982 onward, then a crawling peg was reintroduced. At the same time, the uniform tariff was raised in stages to $35 \%$ by September 1984 (with annual averages of $24 \%$ and $26 \%$ in 1984 and 1985 , respectively). Subsequently, as the acute shortage of foreign exchange eased, the tariff was reduced in stages to $30 \%$ in March $1985,20 \%$ in June the same year, $15 \%$ in 1988 and $11 \%$ in mid- 1991 .

After the 1982 crisis, trade policy was modified in a number of ways. The Government began to make active use of antidumping measures to protect the economy from unfair trading practices. For this purpose, it raised the total tariff (the uniform tariff plus countervailing surcharges) to a maximum of $35 \%$-the level bound by Chile in the General Agreement on Tariffs and Trade (GATT) in 1979-for imports that Chile could prove were being dumped. A system of price bands consistent with medium-term international prices was introduced for three leading agricultural products (wheat, sugar and oilseeds), which yielded significant benefits for agriculture. Of course, it was also a departure from the uniform tariff, although it was viewed more as a price stabilization mechanism for the imports affected. Where exports were concerned, drawback systems were improved and a system of simplified tax rebates was adopted for minor exports, which qualified for reimbursement of up to $10 \%$ of their value when the total value of all exports in the customs item concerned did not exceed a certain yearly limit (Macario, 2000). In 1996, according to information from the Central Bank, $16 \%$ of exports benefited from this incentive and the average drawback was $8.7 \%$ of the value of these exports. Box 1 summarizes the main export promotion mechanisms.

One of the most striking export initiatives was developed by a semi-public foundation, Fundación Chile. The early projects of the Foundation were mainly focused on providing technical assistance to particular sectors. Few got beyond the pilot stage, however. In view of these problems, the Foundation decided to gain experience by initiating business ventures itself. The idea was to determine what activities could benefit from new technologies, so that these could then be acquired and adapted. Once a technology had been assimilated,

\footnotetext{
${ }^{3}$ Worsening terms of trade, higher interest rates on the external debt and a sudden halt to lending by foreign banks (Ffrench-Davis, 2002, chapter VI).
}

the Foundation would carry out commercial production, with marketing to be conducted by a subsidiary. When the subsidiary became profitable it would be sold off, and the technology transfer process thereby completed.

One very successful example was salmon farming. In 1981, the Foundation decided to conduct a pilot cagebased freshwater salmon farming project. Commercial production began in 1986-1987, and doubled the following financial year. In 1988 the project went into profit, and the transfer cycle was completed that year when the Foundation sold it on to a Japanese fish and shellfish company. The Foundation's salmon farming project gave a clear boost to salmon production in Chile, and in the 1990s salmon became one of the country's main exports, and the leading non-traditional one (ECLAC, 1998).

To sum up, a "second trade reform" began in 1983, involving a mixture of restrictions, liberalization and intervention (table 1). While the basic characteristics of trade policy -the abolition of non-tariff barriers and the adoption of a uniform tariff- had not changed since 1979, the tariff had risen back to quite a high level by 1984 , and was now accompanied by antidumping measures and price bands. In fact, the tariff averaged $20 \%$ in 1984-1989, double the average for 1979-1982. The fundamental difference, however, lay in the fact that during the first liberalization the exchange rate appreciated progressively through the second half of the 1970 s and early 1980 s. In the 1980 s, on the other hand, as the tariff was being cut from 35\% in September 1984 to $15 \%$ in 1988 , the currency underwent a large real devaluation under the pressure of the debt crisis, which sent out a powerful positive signal to exporters while at the same time stimulating the production of import-competing goods. Thus, in this second episode, by contrast with the first, the output of importables also recovered strongly, chiefly between 1984 and the late 1980s.

If conclusions are drawn about the different stages of trade liberalization in Chile, it is clear that the net results of the second reform were better than those of the first (ECLAC, 1998, chapter V).

\section{Exchange-rate policy}

Exchange-rate policy has varied greatly. From 1976 onward, real exchange-rate appreciation was used sporadically to anchor inflation (Ffrench-Davis, 2002, chapter IV). This was because inflation remained stubbornly high despite a deep recession that produced a current-account surplus in 1976. Currency 
Box 1

TAX INCENTIVES FOR EXPORTS BY THE LATE 1980S

- Exemption of exports from value-added tax (VAT) and reimbursement of taxes paid on inputs incorporated into export products. This instrument was designed to avoid double taxation of final products or "tax exporting" (Decree-Law 825, in force since 1974).

- Simplified tax rebates or drawback for minor exports (non-traditional products) involving refund of $10 \%$ or $5 \%$ of the FOB value exported (Act 18.480, in force since 1985).

- Duty and VAT waiver for inputs imported for use in producing export goods on premises designated for that purpose (Fiscal Decree 224, in force since 1986).

- Deferred payment of customs duties on imports of capital goods. This instrument is of general application and is not exclusive to exporters (Act 18.634, in force since 1987).

- Rebate of customs duties paid on imported inputs incorporated into export products (Act 18.700, in force since 1988).

Source: Ffrench-Davis, Leiva and Madrid (1991) and Macario (2000).

appreciation intensified in 1979 when the peso was set at 39 to the dollar, a nominal parity that survived until the mid-1982 crisis; during those years, very substantial real appreciation took place. The currency crisis of 1982 was followed by some months of experimentation, with a succession of policies being followed. In 1983 a crawling peg was adopted again, and this policy was maintained with some variations until 1999. Essentially, the Central Bank set a reference price for the dollar in the official market (called the "tipo de cambio acuerdo" or TCA), with an initially small flotation band that was widened every so often. The "official" exchange rate was devalued each day in accordance with the differential between domestic inflation and estimated external inflation. One-off devaluations were also carried out on a number of occasions, culminating in the enormous real depreciation seen after the 1982 crisis (130\% between 1982 and 1988).

Because a number of exchange controls remained in force for many years (except for a few weeks in 1982 when all exchange controls were lifted), an illegal (but openly tolerated) parallel currency market operated. This would be legalized as the "mercado cambiario informal" (MCI) only in April 1990, by virtue of the Central Bank independence act issued by Pinochet's Government at the very end of his 16 years in power.

In 1988, currency appreciation accompanied by tax and tariff cuts (see the next section) reconciled lower inflation with a strong economic recovery. By 1989 the recovery was complete and the output gap between actual GDP and potential GDP was closed (figure 1). ${ }^{4}$
This was due to a sharp increase in aggregate demand, sustained by the tax cuts and currency appreciation of 1988 and the fiscal revenue generated by a large rise in the copper price in 1987-1989; between 1986 and 1988, the terms of trade improved by the equivalent of $6 \%$ of GDP (according to the Central Bank National Accounts, at 1986 prices). A large rise in imports and the external deficit (if the current account is recalculated using the "normalized" price of the Copper Stabilization Fund) and a sharp pick-up in inflation led the Central Bank to reverse previous interest rate cuts.

In mid-1989, the flotation band against the dollar was widened to $\pm 5 \%$. The action of the Central Bank was accompanied by a change in expectations in the currency market, so that the exchange rate rapidly fell to the bottom of the band. Thus, without too much dislocation, a significant depreciation was achieved without any change in the "official" exchange rate. For a year or so, during which time democracy was restored, presidential elections were held (in December 1989) and president Aylwin took office (in March 1990), the bank market rate ("dólar observado") remained at the bottom of the band, even though in January 1990 macroeconomic adjustment efforts were stepped up to check rapidly climbing inflation, which had risen to $31 \%$ on an annualized basis over the previous five months. The sole adjustment measure taken was a sharp interest rate rise, led by Central Bank 10-year paper, which was offered at the high real annual rate of $9.7 \%$.

\footnotetext{
${ }^{4}$ See Ffrench-Davis (2002, chapter I).
} 
FIGURE 1

Chile: Actual and potential GDP per capita, 1974-2001

(1974 per capita GDP $=100$ )

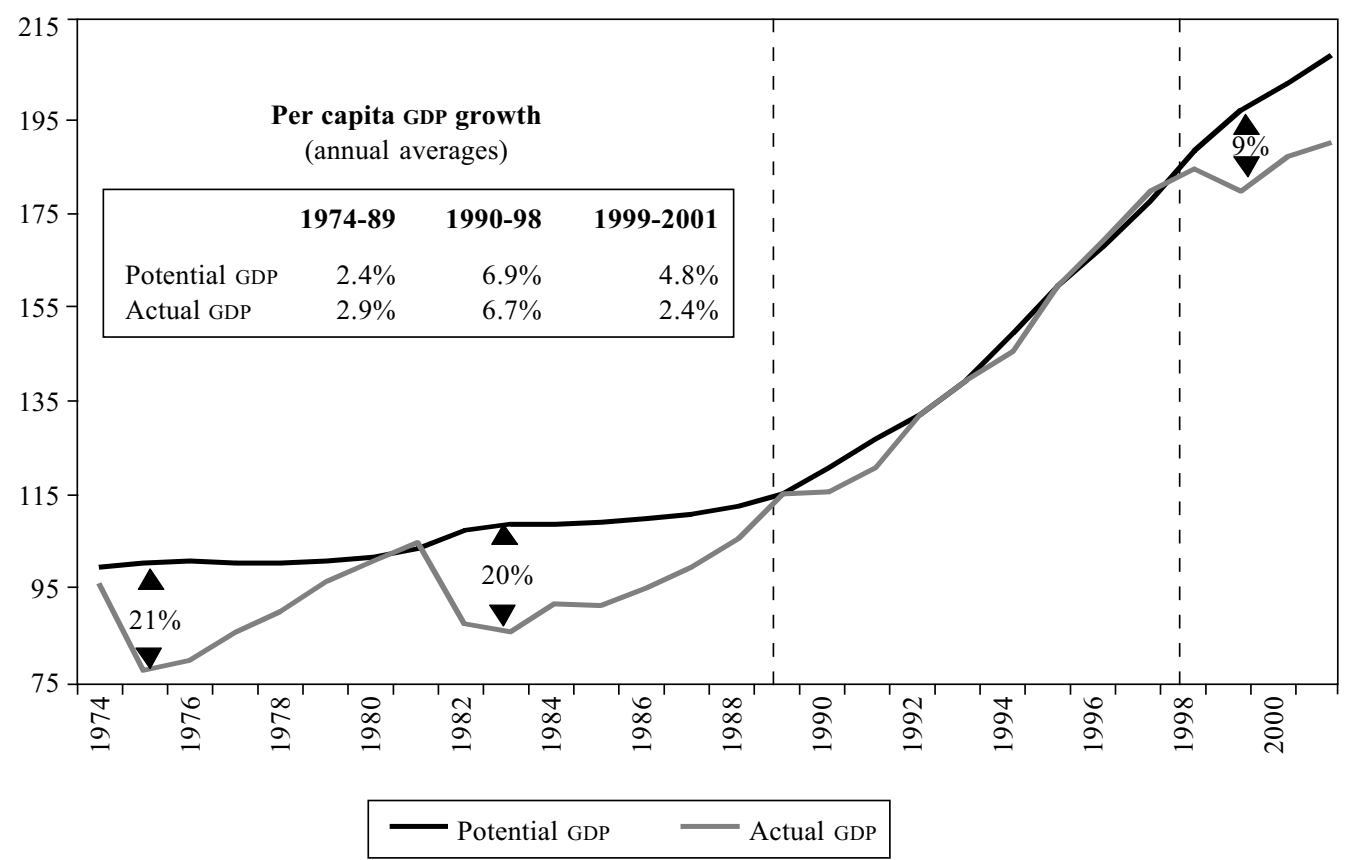

Source: Based on Ffrench-Davis (2002, chapter 1).

\section{III}

\section{Trade policy since 1990}

The economic team that took over in 1990 stuck to the basic principles of the previous trade policy. ${ }^{5}$ The main exception was the decision to sign trade agreements with a number of partners, mainly in Latin America. The economy remained open to trade and a uniform

\footnotetext{
${ }^{5}$ The new approach was consistent with the documented criticism of the shortcomings recorded in the liberalization process, which had led to the sharp de-industrialization of the 1970s and to numerous bankruptcies, but it was also compatible with an awareness that neoliberal reform had begun 16 years previously and culminated in 1979. This was now a given, and there was no question of starting afresh. In Agosin and Ffrench-Davis (1998) we put forward some proposals for "reforming the reforms" to trade and productive development in Chile.
}

import tariff for the rest of the world was retained. The rate of $11 \%$ that applied in 1991 was kept unchanged until 1999, when it began to be gradually reduced with a view to bringing it down to $6 \%$ after five years, in 2003. In a significant "reform of the reforms", however, macroeconomic policies were altered substantially (Ffrench-Davis, 2002, chapters I and IX). The most important outcome was vigorous export expansion, now achieved in tandem with dynamic GDP growth.

\section{Towards a "reciprocated" policy}

Without a doubt, the most outstanding feature of Chilean trade policy in the 1990s was the search for 
arrangements to expand the country's access to new export markets. The new domestic political scene opened the way for a marked shift in Chile's position, away from an across-the-board, unilateral approach to liberalization informed by a preference for neutral policies and an arm's length attitude to Latin America, and towards a strategy that included preferential free trade agreements subject to reciprocity (with many countries in the region, in the event) and more active promotion policies.

Since by that time the Chilean economy was already highly open to trade, it was judged that in a world where trading areas and economic blocs were becoming increasingly important, the benefits of further unilateral liberalization would be small (Ffrench-Davis, 1999, chapter VIII.1). Progress towards economic integration in Latin America was envisaged as a form of open regionalism.

In pursuit of an active policy, economic complementation agreements were signed with Andean Community countries, i.e., Bolivia (1993), Venezuela (1993), Colombia (1994), Ecuador (1995) and Peru (1998), and with the Central American Common Market (1999). In the case of the Southern Common Market (Mercosur), the main market in Latin America that includes Argentina, Brazil, Paraguay and Uruguay, an agreement was signed in 1996, stipulating that a free trade area would be in operation by 2004 .

Far-reaching integration was achieved with Mexico (1991 and 1999) and Canada (1997), thanks to quite comprehensive free trade agreements. For example, the agreement with Canada contains a special clause allowing Chile to apply capital controls, particularly the reserve requirement which Chile established in 1991 to moderate the large inflow of funds recorded then and shift their composition away from short-term and volatile flows.

Stronger links with other regions were another ingredient in Chile's international policy. This resulted in negotiations with the European Union, the United States and Asia-Pacific countries.

Domestically, trade policy in the 1990s had to deal with a situation quite different from the previous decade's. Successive GATT negotiating rounds and the rules subsequently laid down by the World Trade Organization (WTO) restricted the use of export subsidies in developing countries. Consequently, the use of simplified tax drawback schemes and deferred payment of customs duties on imported capital goods, instruments that had proved highly effective and efficient in the 1980s and early 1990s, was heavily restricted and is due to be discontinued by January 2003.
In the $1990 \mathrm{~s}$, then, the authorities' export development efforts largely centred on ways of correcting some market distortions more directly. The main programme, administered by the national export promotion body (ProChile), supplies information to potential exporters and supports activities to promote Chilean products in new markets. These policies were successful in facilitating market access for participating firms (Alvarez and Crespi, 2000), but they were far from being as vigorous as the rather unorthodox exporting strategy of the 1980s (including simplified drawback and incentives such as debt-equity swaps with an implicit subsidy of $46 \%){ }^{6}$ This was certainly given a decisive boost by the real devaluation of $130 \%$. This devaluation was prompted, or forced, by the acute external debt crisis and the consequent need to "produce" dollars by exporting and "save" dollars by substituting imports or producing importable tradables.

\section{Exchange-rate policy and the new capital surge}

For most of the 1990s the crawling peg system was maintained, but with much more active intervention. As in other Latin American and emerging countries, the Chilean authorities had to cope with a sharp resurgence of private-sector capital inflows which pushed exchange-rate policy decisively in the opposite direction from the 1980 s, when the pressure was towards depreciation. Owing to the scale of these inflows, the real exchange rate in Chile tended to appreciate during the first half of the decade (see figure 2 and Ffrench-Davis, 2002, chapter IX). However, the effective appreciation was significantly less than in other countries; furthermore, the fact that Chile was emerging from the severe external debt crisis of the 1980s meant there was room for appreciation since, up to a point, this represented movement towards equilibrium rather than away from it.

Broadly speaking, the moderate level of the current-account deficit in the first half of the 1990s indicates that the appreciation really did represent a movement towards equilibrium; this is consistent with net productivity increases and the improvement in external debt conditions. The external deficit actually averaged just $2.5 \%$ of GDP in 1990-1995, by comparison with the $8 \%$ seen in Mexico prior to the "Tequila" crisis.

\footnotetext{
${ }^{6}$ This refers to the so-called "chapter XIX", which operated in Chile between 1985 and 1991 with large implicit subsidies for those foreign investors bringing Chilean external debt paper (see FfrenchDavis, 2002, chapter VII).
} 
FIGURE 2

Chile: Real exchange rate, 1974-2001

$(1974=100)$

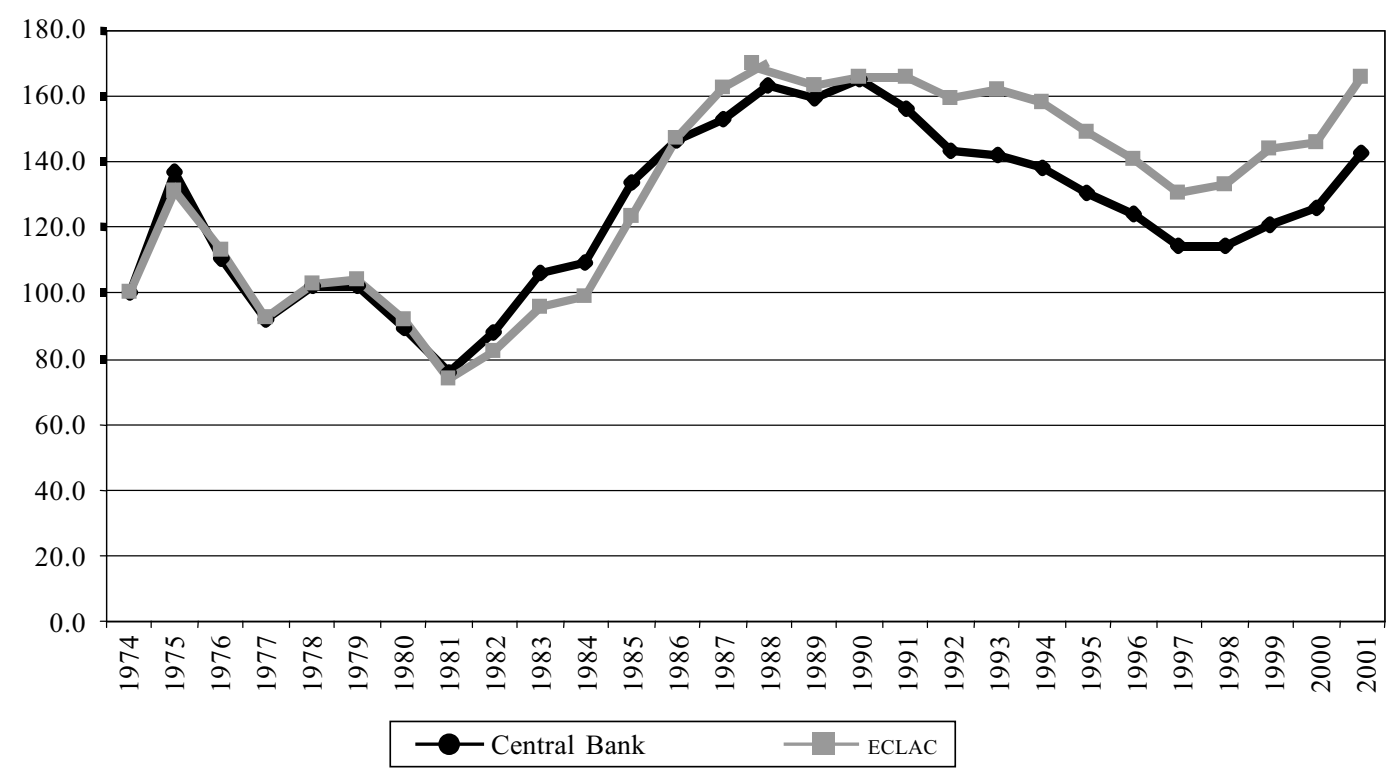

Source: Central Bank of Chile, ECLAC and Ffrench-Davis (2002, figure IX.3). The main difference between the two indicators is that ECLAC uses the consumer price index to measure external inflation and the Central Bank uses wholesale prices. The first method is more consistent with estimates available for other Latin American countries.

In Chile, significant changes were made to exchange-rate policy to counter the tendency towards appreciation; thus, after being linked only to the United States dollar, the exchange rate was tied to a basket of currencies with a view to discouraging speculative capital flows, most of which were in dollars, and the Central Bank became actively involved in the currency market, where its activities included intra-margin intervention (within the band). Taxes and reserve requirements were also imposed on external credits and foreign-currency deposits, the idea being to increase their cost in the domestic market and thereby dampen the supply of currency being generated by the capital surge and reduce the share of short-term flows. Defending the exporting model was an explicit objective of this effort to avoid excessive real currency appreciation and instability (Zahler, 1998).

Prudential macroeconomic policies lost some of their effectiveness in the second half of the decade, when the Central Bank failed to react forcefully and quickly enough to a massive new capital inflow. Flows into Latin America rose substantially in 1996-1997, and this overabundance was felt particularly in Chile. In the face of this, the Central Bank choose to keep cost restrictions (the reserve requirement) at existing levels. As a result, the Chilean foreign-exchange and credit markets were flooded by funds to a greater extent than in 1990-1994. The reserve requirement was generally paid, but it was less than the returns expected from investing in Chile. Thus, excess supply built up in the Chilean market. The scale of outside flows resulted in a real appreciation of $16 \%$ between 1995 and October 1997 and in a rise in the external deficit, which peaked at $5.7 \%$ of GDP in the 1996-1997 biennium. To maintain the equilibria of the real macroeconomy, the natural response would have been to raise the reserve requirement (Le Fort and Lehmann, 2000).

Thus, when the Asian crisis hit Chile, the exchange rate was overvalued. The expectation of an imminent devaluation triggered further capital flight, with all the downward pressure on the currency this entailed. The Central Bank resisted this pressure by narrowing the band and raising interest rates, until in September 1999 it decided to let the currency float freely. This change made it possible for the real exchange rate to begin a sharp adjustment from its hitherto very overvalued level, but subsequently it also meant greater volatility. ${ }^{7}$

\footnotetext{
${ }^{7}$ Caballero and Corbo (1989) have shown empirically that real exchange-rate volatility has highly negative effects on export performance.
} 


\section{IV}

\section{Export performance}

\section{Export dynamism}

Since the 1970s, two cycles in Chilean export growth can be distinguished. As table 2 shows, these represent a step-change from the historical trend. The first cycle lasted from 1974 until the late 1970s. In eight years, export volume growth averaged $9 \%$ a year, but the rate for non-copper exports was $16 \%{ }^{8}$ In the early 1980 s total and manufactured exports stagnated, owing to the substantial real currency appreciation that took place in Chile and to the cooling of the world economy. Thus, in 1981 export volumes fell by 3\%, dragged down by a fall of 7\% in non-copper exports (Sáez, 1991).

The second cycle of rapid export growth began after 1982, when the real exchange rate underwent a sharp devaluation. Table 2 shows that in the second half of the decade, the slow growth of copper export volumes was compensated by the spectacular rise in other export categories. The volume of traditional exports other than copper grew by $9 \%$ a year over the four-year period 1986-1989, but it was non-traditional exports that showed the greatest dynamism, with shipments expanding by $22 \%$ a year.

Export volumes continued to rise vigorously in the 1990 s, at an annual average of $9 \%$ (1990-2001). This is basically accounted for by the performance of nontraditional exports, which grew by $13 \%$ a year, while shipments of copper and other traditional products increased by $9 \%$ and $5 \%$, respectively. The value of primary commodity exports did not change much in the first half of the 1990s, owing to the decline in the copper price. In 1994-1995, prices for the main exports picked up sharply, which contributed to the vigorous growth they displayed over the biennium. This boom was cut short by the Asian crisis, which struck the economies of Latin America in 1998-1999, causing a negative terms of trade shock so that the value of exports, particularly traditional ones, fell substantially. The index of unit export prices fell by $9 \%$ over the biennium. The instability of export prices (and of the

\footnotetext{
${ }^{8}$ It is interesting to note the spectacular rise in exports in 1974 , reflecting very considerable underutilization of export capacity the year before. Export volume rose by $38 \%$ in 1974 , then by $7 \%$ a year on average in 1975-1980, before falling in 1981.
}

terms of trade) is one of the drawbacks affecting this variable of such key importance to economic development in Chile.

There is another disturbing factor that deserves closer consideration. While growth in the physical volume of non-traditional exports has been exceptional, this dynamism has gradually being falling away: growth averaged $22 \%$ a year in $1986-1989,16 \%$ in $1990-1995$ and $10 \%$ in 1996-2001 (table 2, p. 144). Consequently, the volume growth of these exports has tended to converge, perhaps prematurely, with the average volume growth of total exports (figure 3, p.145). Slower growth in traditional exports other than copper during 19962001 was offset by the dynamism of copper exports, whose physical volume increased at an annual rate of $12 \%$ (15\% in 1995-1999). As Moguillansky (1999) and Sachs, Larraín and Warner (1999) document, however, these very impressive growth rates appear to be unsustainable, both because investment is falling and because there are external markets in which Chile has become a "major" exporter in a number of categories.

The real currency appreciation that occurred in the second half of the 1990s, and its impact on the competitiveness of the export sector, seems to be the main reason for the slackening of non-traditional export growth (Díaz and Ramos, 1998). This hypothesis is given support by the econometric estimates of Moguillansky and Titelman (1993) for the priceelasticity of Chile's export supply in different industries. These authors conclude that the effects of variations in the real exchange rate differ depending on the type of goods being exported, and that a systematic real depreciation (appreciation) tends to have a positive (negative) impact on volume and on diversification into greater value-added. Thus, depreciation of the currency followed by stability at the new rate is likely to prove an incentive for investment in tradables and export diversification.

In the 1990s, the pattern of trade growth was greatly influenced by foreign direct investment (FDI), which affects both exporting capacity and the exchange rate. In fact, FDI has made a major contribution to export development in Chile. In the period 1990-2000, it is conservatively estimated that about $30 \%$ of the resources invested in tradables were channelled through 
TABLE 2

Chile: Export volume growth, 1961-2001

\begin{tabular}{lcccrrr}
\hline & $1961-1970$ & $1971-1973$ & $1974-1985$ & $1986-1989$ & $1990-1995$ & $1996-2001$ \\
\hline Copper & & -2.3 & 5.0 & 3.3 & 6.5 & 11.4 \\
Non-copper & 3.9 & -8.5 & 15.8 & 13.1 & 11.2 & 7.0 \\
$\quad$ Traditional & 7.8 & & & 9.0 & 7.7 & 2.9 \\
$\quad$ Non-traditional & & & & 21.7 & 15.2 & 10.3 \\
Total exports & 4.9 & -4.5 & 9.3 & 8.8 & 9.2 & 8.8 \\
\hline
\end{tabular}

Source: Sáez (1991) for 1960-1985 and Central Bank of Chile for 1985-2001. Exports FOB.

FDI, the main destination being copper production. ${ }^{9}$ This large contribution to export capacity was eroded, however, in the second half of the decade. In 19901995 , FDI in export sectors accounted for $75 \%$ of total FDI flows. In 1996-2000, however, the share was down to $35 \%$ (ECLAC, 2001). ${ }^{10}$

The declining share of FDI in tradables production was offset by the sharp rise in total FDI. Larger flows, on top of higher portfolio inflows during those years, were partly responsible for the overvaluation of the peso in 1996-1997. ${ }^{11}$ This process not only had negative macroeconomic effects (see Ffrench-Davis, 2002, chapter IX), but was detrimental to production as well, owing to the spread of so-called "Dutch disease" in most export sectors, particularly non-traditional ones which, as has now been documented, react more elastically to the level and stability of the real exchange rate. All this is consistent with the surge in copper export volumes and the slackening of other exports. It highlights the importance of having a broader set of policies to ensure sound export development.

\footnotetext{
${ }^{9}$ However, the domestic value-added in this copper output is notably lower than that of the State enterprise Codelco, because privately produced copper is less highly processed and effective taxes on profits are very low.

${ }^{10}$ In addition, a large percentage of FDI in the latter part of the 1990s went into mergers and acquisitions of existing assets, operations that did not directly result in the creation of new productive capacity. This is borne out by the contrast between huge FDI inflows -some US\$ 17 billion in 1999-2001, or 8.4\% of GDP, the highest since figures became available- and the declining growth rate of potential GDP $(4.8 \%)$ and actual GDP $(2.4 \%)$.

${ }^{11}$ In those years proposals were made for rationing FDI in copper production by an auctioning process. The idea was to reduce the inflow (thus checking currency appreciation), moderate the downward pressure on the future price of copper and capture some of the economic rent from reserves, which were taxed only lightly and without regard to the quality of the natural resource (Agosin and Ffrench-Davis, 1998).
}

\section{Export composition}

Chilean exports have been diversifying in recent decades, but they are still natural resource-intensive. The share of copper exports in the total fell from $70 \%$ in 1970 to about $45 \%$ by the early 1980 s, and stayed at around this level until the 1990s, when it fell below $40 \%{ }^{12}$ This decline is partly explained by the fall in the copper price during the first half of the 1990s, and the more rapid drop seen in recent years. Meanwhile, the trend towards diversification can also be observed in the number of products sold abroad, which increased from 200 in 1970 to 2,800 in 1990 and about 3,900 in 1996 , before stabilizing at that level. Something similar happened with the number of exporters, which rose spectacularly until the mid-1990s before settling at about 6,000 .

Traditional exports other than copper-consisting of fresh fruit and natural resource-based manufactures, including fishmeal, cellulose and paper- increased substantially in the 1970 s, jumping from $24 \%$ to $40 \%$ of total goods exports between 1970 and 1979. In the early 1980s the real value of these exports fell off, owing to the detrimental effects of currency appreciation, and over the decade their share fell to a third of the export total. In 1987 they began to increase again in real terms, although more slowly than other exports, and with large fluctuations. As a result, by the end of the 1990s their share was less than $30 \%$.

Non-traditional exports - a category which includes non-natural resource-based manufactures and new products based on non-traditional natural resourcesinitially grew very strongly during the first trade reform.

\footnotetext{
${ }^{12}$ During the 1980s the copper production costs of most of the world's major mining companies fell substantially. For this reason, the "normal price" expected for the metal over the years that followed tended to be much lower than in previous decades (Bande and Ffrench-Davis, 1989, and Vial, 1988).
} 
FIGURE 3

Chile: Value of goods exports, 1970-1998

(Millions of 1986 dollars)

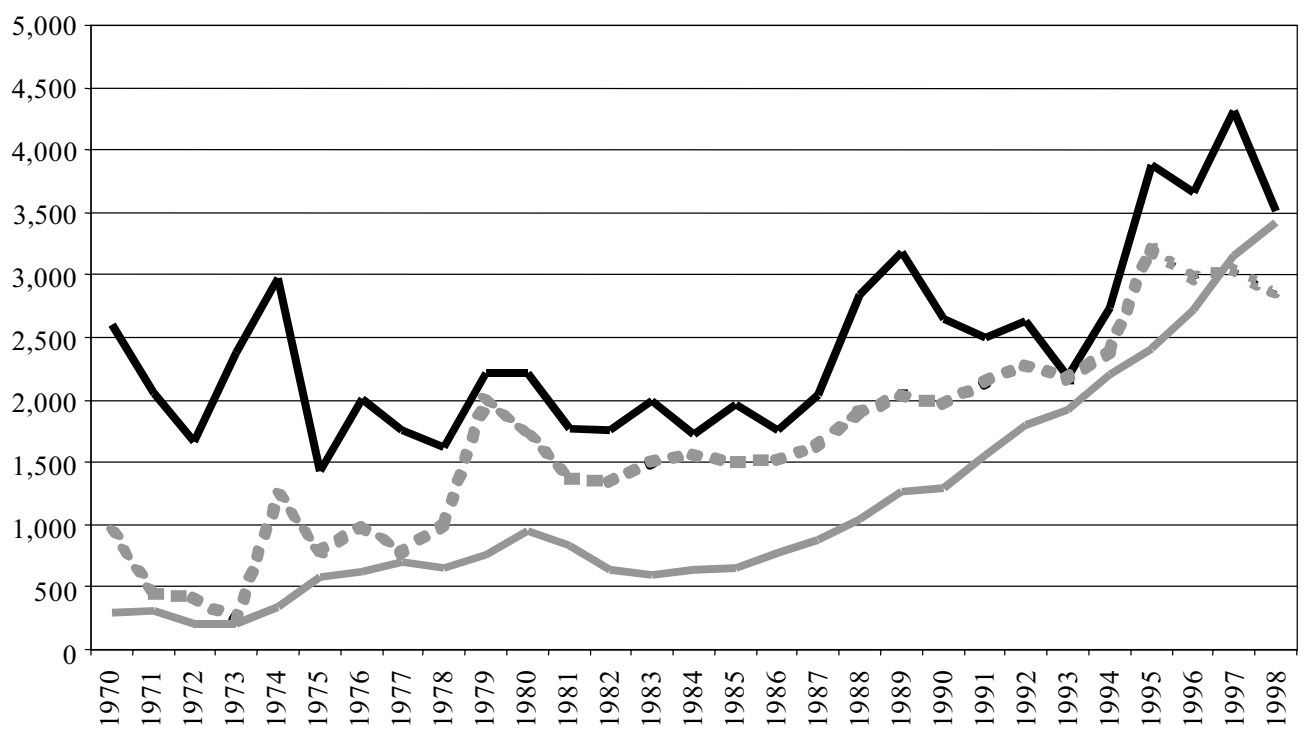

\section{Copper . . . . Traditional non-copper $\quad$ Non-traditional}

Source: Author's calculations based on BADECEL. The series were deflated by an external price index relevant to Chile.

Their share increased from less than $10 \%$ in 1970 to about $20 \%$ in the second half of the decade, but then it fell off in the early 1980s, actually decreasing substantially in 1981. As already noted, from the mid1980 s this group saw vigorous, sustained growth again, so that its share rose to $35 \%$ in the second half of the 1990 s, matching the value of copper exports towards the end of the decade.

Table 3, p. 146, shows the geographical distribution by value of Chilean exports, broken down by technology content, over the last three decades. The technology classification, which is based on ECLAC (1992), groups products into three categories: unprocessed commodities (line a), which are natural resources with little value added; semi-processed commodities (line b), which are natural resources that have been subjected to some degree of processing, and manufactured products (line c), encompassing technologically more complex goods.

The first column of the table shows that, despite the diversification of recent years, and notwithstanding the tendency to export more highly processed goods, Chilean sales abroad continue to rely heavily on natural resources. In fact, even non-traditional exports include a large share of goods that are intensive in such resources (line b). The table reveals that the share of natural resource-based exports in the total was more than $85 \%$ in 1998 . This is not surprising when it is considered that Chile is endowed with rich natural resources plus geographical factors generating natural comparative advantages that are highly static. It is for this reason, though, that prices for Chilean exports are so unstable, and demand so sluggish. The table also shows that no vigorous or systematic enough effort has been made to achieve a more substantial shift in the country's export profile.

\section{Diversification of destination markets}

Exports have diversified in terms not only of products, but of destination markets as well. The number of markets rose from 31 in 1970 to 120 in 1987 and 174 in 1999. The European Union has traditionally been the largest destination for Chilean exports. In 1970, for example, $61 \%$ of exports went to Europe (table 3, line d).

After the first trade liberalization the geographical distribution of exports changed, mainly owing to the increasing importance of the Latin American and North American markets, which cut into the European Union 
TABLE

Chile: Geographical distribution of exports by technology content, 1970-1998

\begin{tabular}{|c|c|c|c|c|c|c|c|c|}
\hline \multirow[t]{2}{*}{ Year } & \multirow[t]{2}{*}{ Product type } & \multirow{2}{*}{$\begin{array}{l}\text { Composition } \\
\text { (\% of total) }\end{array}$} & \multicolumn{6}{|c|}{ Geographical distribution (\%) } \\
\hline & & & $\begin{array}{c}\text { Latin } \\
\text { America }\end{array}$ & $\begin{array}{c}\text { European } \\
\text { Union }\end{array}$ & $\begin{array}{l}\text { United } \\
\text { States }\end{array}$ & Japan & Asia & Others \\
\hline \multirow[t]{4}{*}{1970} & a) Non-processed commodities & 12.9 & 10.6 & 33.0 & 14.9 & 39.8 & 0.1 & 1.6 \\
\hline & b) Semi-processed commodities & 84.5 & 10.3 & 67.1 & 14.2 & 7.8 & 0.4 & 0.2 \\
\hline & c) Manufactures & 2.2 & 62.6 & 2.2 & 10.1 & 13.0 & 1.0 & 11.1 \\
\hline & d) Total & 100.0 & 11.5 & 61.1 & 14.1 & 12.1 & 0.4 & 0.8 \\
\hline \multirow[t]{4}{*}{1983} & a) Non-processed commodities & 27.2 & 9.2 & 25.0 & 26.7 & 25.7 & 8.4 & 5.0 \\
\hline & b) Semi-processed commodities & 66.8 & 11.3 & 43.1 & 27.8 & 3.1 & 7.7 & 7.0 \\
\hline & c) Manufactures & 6.0 & 33.2 & 17.1 & 35.7 & 2.3 & 4.1 & 7.6 \\
\hline & d) Total & 100.0 & 12.0 & 36.6 & 28.0 & 9.2 & 7.7 & 6.5 \\
\hline \multirow[t]{4}{*}{1989} & a) Non-processed commodities & 26.3 & 13.2 & 27.4 & 20.9 & 19.3 & 15.4 & 3.8 \\
\hline & b) Semi-processed commodities & 66.3 & 10.8 & 43.6 & 14.2 & 12.7 & 13.5 & 5.2 \\
\hline & c) Manufactures & 7.5 & 21.2 & 20.2 & 36.8 & 3.6 & 3.5 & 14.7 \\
\hline & d) Total & 100.0 & 12.2 & 37.6 & 17.7 & 13.7 & 13.2 & 5.6 \\
\hline \multirow[t]{4}{*}{1998} & a) Non-processed commodities & 30.5 & 17.2 & 19.1 & 21.8 & 27.4 & 11.4 & 3.1 \\
\hline & b) Semi-processed commodities & 55.5 & 19.4 & 36.0 & 13.1 & 10.0 & 18.7 & 2.8 \\
\hline & c) Manufactures & 14.0 & 55.7 & 17.3 & 14.2 & 0.6 & 1.1 & 11.1 \\
\hline & d) Total & 100.0 & 23.8 & 28.2 & 15.9 & 14.0 & 14.0 & 4.1 \\
\hline
\end{tabular}

Source: Prepared by the author using BADECEL data. Figures in current dollars, classified in accordance with ECLAC (1992) and Benavente (2001).

share. The severe effects of the debt crisis on Latin America reversed that tendency, so that the share of Chilean exports taken by the region fell to $12 \%$ in 1983 . In that same year, the United States absorbed 28\%, while the share of the European Union fell to 37\% and Asian countries other than Japan emerged as important trading partners, their share rising from close to zero to $8 \%$. By the end of the military dictatorship, in 1989 , the share taken by United States markets had slipped to $18 \%$, with an offsetting rise to $27 \%$ in the share going to Asian destinations.

In the 1990s, the share of United States markets held steady while that of the European Union declined, although it remained the largest destination in 1998. Asian markets continued to grow in importance, and in 1997 their share of Chilean exports (almost exclusively natural resources) peaked at $35 \%$, making them the largest destination. This growth in the share taken by Asian markets was reversed in 1998, owing to the crisis that originated in that region. The collapse of Asian markets, whose share fell by seven percentage points, is one of the factors accounting for the severe drop in Chile's export total in 1998-1999. Exports to Latin American countries rose vigorously, thanks to the implementation of free trade agreements covering most of the region's markets, an upsurge in economic activity and the real appreciation of their currencies in relation to other parts of the world. As a result, the share of regional markets had risen to $24 \%$ by 1998 , just before the Asian contagion reached Latin America.

The composition of Chilean exports differs greatly by geographical destination. The figures in table 3 show that exports to industrialized countries are much more dominated by processed and unprocessed natural resources than are exports to markets in the region. The contrast is marked: in 1998, manufactures accounted for $56 \%$ of all Chilean exports to Latin America (a considerable increase on the $21 \%$ recorded in 1989), but for only $17 \%$ of Chilean exports to the European Union, $14 \%$ of those to the United States and $2 \%$ of those to Asia. The huge importance of Latin American markets as a destination for manufactures could be crucial for future progress with the volume and quality of Chilean exports. As was mentioned earlier, these markets have been highly dynamic, their share doubling between 1989 and 1998 .

Within the region, Mercosur is Chile's main trading partner. The share of this market in Chile's total exports to Latin America declined during the 1990s. Nonetheless, the share of manufacturing exports going 
there rose from about $40 \%$ in the 1980 s to about $50 \%$ in the $1990 \mathrm{~s}$, which is indicative of the strategic importance of Mercosur for export diversification and upgrading. As regards the other markets of Latin America, the most dynamic one is Mexico, which is taking an increasing share of both total and manufactured exports.

Thus, the countries of Latin America are playing an increasingly important role in raising the share of manufactures and services in Chile's export diversification process. This development is closely bound up with trade liberalization in the region, including regional integration agreements.

Despite this, questions remain about the sustainability of Chilean manufacturing export growth. Much of the demand for these products still depends on the performance of the region's economies, on macroeconomic stability, and on the maintenance of exchange rates favourable to intraregional trade. In addition, the process will only remain dynamic if productive capacity is increased in activities that are more intensive in value-added and innovation.

\section{Exports and growth}

It has often been asserted that exports are the engine of the Chilean economy. The growth of exports as a share of GDP is obviously a channel for the transmission of externalities deriving from the exposure of local companies to markets abroad. The incidence of these is difficult to quantify, however, and little research has been done. ${ }^{13}$ Again, the crowding-in effect of exports depends on the way they feed back into the national economy. ${ }^{14}$ Progress has unquestionably been made in recent decades, as natural advantages have been supplemented by the development of dynamic competitive advantages, many of them based on natural resources, with the emergence of clusters specializing in forestry products, wine, salmon and fresh fruit. Some analysts believe that these successes could help provide the basis for a "Nordic" development strategy in Chile, whereby value is added to natural resources directly or by services, inputs and capital goods associated with them (Díaz and Ramos, 1998).

There are several arguments for further diversification into more highly processed goods and services, and against passive acceptance of an export profile dominated by products that only make intensive

${ }^{13}$ See Macario (2000) for a pioneering analysis covering Brazil, Chile, Colombia and Mexico.

${ }^{14}$ Another very important variable is the limited share of GDP represented by exports. At late 1990s prices, gross goods and services exports represented less than $30 \%$ of GDP. If this figure is adjusted for the imported component of exports, their net value falls to between $21 \%$ and $24 \%$ of GDP. Thus, a rapid rise in exports -of $12 \%$ a year, say, as in East Asia- provides a growth floor of less than $3 \%$. use of natural resources. There are four important reasons to diversify further with a view to adding more value. Firstly, the fact that primary commodities still make up a large percentage of Chilean exports means that the economy as a whole is still highly vulnerable to the large, unpredictable swings to which raw material prices are always subject. Secondly, there is a limit to how dynamic these products can be in the long term, and this could have adverse consequences for future growth in the economy as a whole (Sachs, Larraín and Warner, 1999). Thirdly, diversification would rapidly feed back into positive effects for the rest of the economy (greater correlation or linkages between exports and the other components of GDP). Fourthly, production of more highly processed goods would bring positive externalities for the rest of the economy in the medium term, owing to the "learning by doing" effect and to the benefits that accrue when dynamic competitive advantages are secured (ECLAC, 1998, chapters III and IV).

Here we shall concentrate on another relationship, the influence of domestic policies - mainly the shifting macroeconomic environment- on the association between the performance of exports and the other components of GDP.

The correlation between export growth and real GDP has actually been high since the recovery from the debt crisis, in the 1990s. There was also a strong association in the recovery periods that followed the 1975 and 1982 crises (Meller, 1996). In those periods, the export sector was one of the most dynamic in the economy. This dynamism was accompanied in the 
1970 s and 1980 s by a recovery in GDP, while in the 1990s Chile's productive capacity expanded strongly as the country embarked on the longest period of sustained growth in its history. In all episodes, export volumes grew much more quickly than GDP (table 4). Most econometric studies that have examined the issue have found a clear positive association between exports (particularly non-copper exports) and GDP growth. ${ }^{15}$

It is important to distinguish, however, between an effect that reactivates aggregate demand and an effect that generates new productive capacity. To concentrate on the latter, table 4 breaks down the last few decades into periods bracketed by years of peak utilization of productive capacity, in 1974, 1981, 1989 and 19971998. To repeat something that is often forgotten, a sector can only really become a growth engine if its expansion feeds back into the creation of new productive capacity in the rest of the economy, something that was only recorded in the 1990s.

As has been pointed out, the external debt crisis and the automatic adjustment that resulted from it led to a decline in output across the board in 1982-1983, with GDP falling by some $14 \%$. In this process, the application of policies to restrain demand resulted in a high degree of productive capacity underutilization. Because the currency was devalued so much, stimulating output of exportables and importables, this underutilization was naturally concentrated mainly in non-tradable goods and services.

The export promotion measures taken during the 1980 s, summarized earlier, acted as supply switching policies, reallocating available resources among sectors at a time when the total investment rate was very low (and thus new capacity creation was weak overall). Depressed domestic demand, and the increased profitability of exports that resulted from currency depreciation, generated incentives to invest in and produce tradables. As a result, there was no export-led growth that decade, but rather an export surge deriving from the combination of binding external constraints and a recessionary internal adjustment. The vigorous growth of exports, which averaged $8 \%$ a year in the period 1982-1989, obviously helped to revive economic activity. It was not enough, however, to make up for the virtual stagnation of non-export GDP, which rose by a mere $1.1 \%$ a year at a time when the population was growing at $1.6 \%$. Exports were therefore unable to transmit their dynamism to total GDP, which grew by just $2.6 \%$ a year (table 4 ). This very modest outcome

\footnotetext{
${ }^{15}$ See Agosin (2001), Coeymans (1999) and Meller (1996).
}

can be explained by the fact that goods and services exports are responsible for less than a quarter of total value-added, or GDP.

In the 1990s it was a different story. The capital formation ratio rose to unprecedented levels, surging not just in the export sector but in non-exports as well. The gross fixed capital investment ratio rose from $18 \%$ in 1982-1989 to $28 \%$ in $1990-2000$. Output in nontradable sectors grew at much higher rates than in the 1970s and 1980s. In 1990-1997, for example, growth in infrastructure works and telecommunications was $18 \%$ and $32 \%$, respectively (Moguillansky, 1999). ${ }^{16}$

At the same time, exports remained dynamic even though the real exchange rate appreciated, particularly in 1995-1998 (figure 2). Three factors contributed to this positive outcome. Firstly, world trade was more vigorous. In 1980-1989, the volume of world trade had grown at an annual rate of 3.7\%, but in 1990-1999 the rate was $6.2 \%$. Secondly, Chile secured preferential access to new markets under a variety of trade agreements. Thirdly, the unprecedented rate of productive investment recorded in the period provided the basis for considerable improvements in labour productivity and external competitiveness. Other things also need to be borne in mind. The bulk of the moderate currency appreciation that occurred during the first half of the 1990s was an equilibrating adjustment after the currency drought of the 1980s. In addition, genuinely active policies were applied during those years to enhance export development through prudential management of the capital account and the macroeconomy in general. ${ }^{17}$ As a result, actual growth in total GDP in the 1990s was associated with dynamism in both tradable and non-tradable sectors. In fact, exports and other components of GDP grew by $9.3 \%$ and $5.1 \%$ a year, respectively, in the period 1990 $2000 .{ }^{18}$ Together with full utilization of productive capacity (figure 1), macroeconomic stability and prudential management, this accounts for the rapid rate of growth in the Chilean economy for much of the decade.

\footnotetext{
${ }^{16}$ These figures should be compared with annual growth of $2.6 \%$ for infrastructure in 1982-1989.

${ }^{17}$ See Ffrench-Davis (2002, chapter IX), Ffrench-Davis, Agosin and Uthoff (1995) and Zahler (1998).

${ }^{18}$ Figures based on table 4 . The averages given in the text include the full employment years from 1991-1997 and the slowdown years of 1990 and $1998-2000$. As 2000 was a year with a recessionary gap, potential non-export GDP growth in 1990-2000 was $6.3 \%$ a year, i.e., higher than the actual non-export GDP growth rate of $5.1 \%$.
} 
Chile: Exports and economic growth, 1960-2001

\begin{tabular}{|c|c|c|c|c|c|}
\hline & $\begin{array}{c}\text { GDP } \\
\text { growth }\end{array}$ & $\begin{array}{l}\text { Export } \\
\text { growth }^{\mathrm{a}}\end{array}$ & $\begin{array}{l}\text { Non-export } \\
\text { GDP growth }\end{array}$ & $\begin{array}{c}\text { Exports/GDP } \\
\text { (constant prices) }\end{array}$ & $\begin{array}{c}\text { Exports/GDP } \\
\text { (current prices) }\end{array}$ \\
\hline $1960-1970$ & 4.2 & 3.6 & 4.3 & 11.9 & 14.0 \\
\hline $1971-1973$ & 0.5 & -4.1 & 0.9 & 9.9 & 11.8 \\
\hline 1974-1981 & 3.3 & 13.6 & 1.5 & 20.7 & 21.8 \\
\hline $1982-1989$ & 2.6 & 7.8 & 1.1 & 28.3 & 28.3 \\
\hline 1990-1994 & 7.3 & 10.0 & 6.3 & 34.6 & 31.0 \\
\hline 1995-1998 & 7.3 & 9.5 & 6.4 & 37.7 & 28.4 \\
\hline 1999-2001 & 2.4 & 7.3 & 0.0 & 43.3 & 31.4 \\
\hline
\end{tabular}

Source: Based on official figures from the Central Bank of Chile at constant prices. Exports include goods and non-financial services.

a Discrepancies with table 2 figures are due to differences in sources and methodology.

b Non-export GDP equals total GDP minus the domestic content, that is the value-added, in exports. The share of imported inputs in the gross export total was assumed to be equal to imports of intermediate and capital goods as a share of GDP.

In the second half of the 1990s, however, the real exchange rate appreciated too much owing to a large capital influx that outstripped the ability of the economy to absorb it efficiently and sustainably. As a result, resource allocation was distorted and the external deficit widened excessively, so that in 1996-1998 it was more than twice as large as it had been in 1990-1995. Consequently, there was also some over-investment in non-tradable sectors (particularly construction and trade), while production of tradables (particularly manufactures) fell off.
Thus, the achievements of most of the 1990s, when high export growth was combined with solid expansion of other components of GDP, were reversed. The reasons for this included the severe external shocks experienced by Chile from 1998 onward and the handling of the real macroeconomy, which was more neutral and passive than it had been in previous years. These two factors produced the recessionary macroeconomic environment in which companies had to operate from 1998 onward (figure 1).

\section{VI}

\section{Concluding remarks}

To sum up, the last three decades have been a period of exceptional export growth in Chile. During the second and third of these decades this remarkable performance was associated with unorthodox, quite active policies that sought to keep the exchange rate competitive and generate export capacity rather than confining themselves solely to orthodox economic reform, as happened in the 1970s with unilateral trade liberalization.

Four mutually reinforcing sets of factors seem to be most important in explaining the dynamic performance of Chilean exports. First, a depreciated real exchange rate is a factor of proven importance for the overall path of exports. Second, diversification into goods and services with greater value-added is crucial for improving the quality of exports, as it: i) gives access to more dynamic demand and higher international prices, and ii) strengthens the links between exports and the domestic economy. Important instruments for this purpose are a stable and rather depreciated real exchange rate, incentives such as simplified drawback of duties for non-traditional exports, and intraregional integration. Third, although this is beyond the scope of the present article, a vigorous national effort is needed to "complete" domestic technology and labour training markets and the long-term segments of the capital market if export quality is to be raised. Fourth, the export drive needs to be complemented by a sustainable domestic macroeconomic environment in which actual output is close to potential GDP and key macroeconomic prices are appropriate and conducive to productive development, so that export-led growth can emerge. This was the decisive factor underlying the positive association between export dynamism and sustained GDP growth in Chile for much of the 1990s. 


\section{Bibliography}

Agosin, M.R. (2001): "Reformas comerciales, exportaciones y crecimiento", in R. Ffrench-Davis and B. Stallings (eds.), Reformas, crecimiento y politicas sociales en Chile desde 1973, Santiago, Chile, Economic Commission for Latin America and the Caribbean (ECLAC). The original version ("Trade and growth in Chile") appeared in the CEPAL Review, No. 68, August 1999.

Agosin, M.R. and R. Ffrench-Davis (1998): "La inserción externa de Chile: experiencias recientes y desafios", in R. Cortázar and J. Vial (eds.), Construyendo opciones, Santiago, Chile, Centre for Economic Research on Latin America (CIEPLAN)/ Dolmen Ediciones.

Alvarez, R. and G. Crespi (2000): "Efecto de las políticas de fomento sobre el dinamismo exportador chileno", El trimestre económico, vol. 67(4), No. 268, Mexico City, Fondo de Cultura Económica (FCE).

Bande, J. and R. Ffrench-Davis (1989): Copper Policies and the Chilean Economy: 1973-88, Technical Notes, No. 132, Santiago, Chile, CIEPLAN.

Benavente, J.M. (2001): "Exportaciones de manufacturas en América Latina: ¿Desarme unilateral o integración regional?", Macroeconomía del desarrollo series, No. 3, Santiago, Chile, ECLAC, April.

Caballero, R. and V. Corbo (1989): The effect of real exchange rate uncertainty on exports: empirical evidence, The World Bank Economic Review, vol. 3, No. 2, Washington, D.C., World Bank.

Coeymans, J. (1999): “Determinantes de la productividad en Chile: 1961-97”, Cuadernos de Economía, No. 107, Santiago, Chile, Pontificia Universidad Católica de Chile, April.

Díaz, A. and J. Ramos (1998): "Apertura y competitividad", in R. Cortázar and J. Vial (eds.), Construyendo opciones, Santiago, Chile, CIEPLAN/Dolmen Ediciones.

ECLAC (1992): "El comercio de manufacturas de América Latina: evolución y estructura, 1962-1989", Estudios e informes de la CEPAL series, No. 88, Santiago, Chile.

(1994): Latin America and the Caribbean: policies to improve linkages with the global economy, Santiago, Chile.

(2001): Foreign Investment in Latin America and the Caribbean, 2000, Santiago, Chile.

Ffrench-Davis, R. (1973): Politicas económicas en Chile: 195270, Santiago, Chile, Ediciones Nueva Universidad.

(1999): Reforming the reforms in Latin America: macroeconomics, trade, finance, Basingstoke, U.K., Palgrave Macmillan.
(2002): Economic Reforms in Chile: from Dictatorship to Democracy, Ann Arbor, Michigan, University of Michigan Press.

Ffrench-Davis, R., M.R. Agosin and A. Uthoff (1995): Capital movements, export strategy, and macroeconomic stability in Chile, in R. Ffrench-Davis and S. Griffith-Jones (eds.), Coping with Capital Surges: The Return of Finance to Latin America, Boulder, Colorado, Lynne Reinner.

Ffrench-Davis, R., P. Leiva and R. Madrid (1991): Trade Liberalization in Chile: Experiences and Prospects, Trade Policy Studies, No. 1, Geneva, UnCTAD.

Le Fort, G. and S. Lehmann (2000): "El encaje, los flujos de capitales y el gasto: una evaluación empírica", Documento de trabajo No. 64, Santiago, Chile, Central Bank of Chile.

Macario, C. (2000): Chile: In search of a new export drive, in C. Macario (ed.), Export Growth in Latin America: Policies and Performance, Boulder, Colorado, Lynne Rienner.

Macario, C. (ed.) (2000): Export Growth in Latin America: Policies and Performance, Boulder, Colorado, Lynne Rienner.

Meller, P. (ed.) (1996): El modelo exportador chileno: crecimiento $y$ equidad, Santiago, Chile, CIEPLAN.

Meller, P. and R.E. Sáez (eds.) (1995): Auge exportador chileno: lecciones y desafios, Santiago, Chile, CIEPLAN/Dolmen Ediciones.

Moguillansky, G. (1999): La inversión en Chile: ¿el fin de un ciclo de expansión?, Santiago, Chile, FCE/ECLAC.

Moguillansky, G. and D. Titelman (1993): “Análisis empírico del comportamiento de las exportaciones no cobre en Chile: 1963-1990", Documento de trabajo, No. 17, Santiago, Chile, ECLAC.

Sachs, J., F. Larraín and A. Warner (1999): A structural analysis of Chile's long-term growth: history, prospects and policy implications, report requested by the Chilean Ministry of Finance, Santiago, Chile, unpublished.

Sáez, S. (1991): Indicadores para las exportaciones chilenas: 195089, Technical Notes, No. 138, Santiago, Chile, CiePLAN.

UNCTAD (United Nations Conference on Trade and Development) (1992): Trade Liberalization in Chile: Experiences and Prospects, Trade policy series, No. 1, New York.

Vial, J. (1988): An Econometric Study of the World Copper Market, Technical Notes, No. 112, Santiago, Chile, CIEPLAN.

Zahler, R. (1998): The Central Bank and Chilean macroeconomic policy in the 1990s, CEPAL Review, No. 64, LC/G.2022-P, Santiago, Chile, ECLAC. 